\title{
The Brain-Specific Gene 1B236 Is Expressed Postnatally in the Developing Rat Brain
}

\author{
Dominique Lenoir, Elena Battenberg, Mary Kiel, " Floyd E. Bloom, and Robert J. Milner \\ Departments of Basic and Clinical Research and *Molecular Biology, Research Institute of Scripps Clinic, La Jolla, \\ California 92037
}

The rat brain-specific polypeptide $1 \mathrm{~B} 236$ was previously characterized by molecular cloning and nucleotide sequence determination of its mRNA. It has been shown to exist in rat brain in discrete neuronal circuits, primarily as a 100,000 Da glycoprotein. We now have determined the time course of expression of $1 \mathrm{~B} 236 \mathrm{mRNA}$ and protein in rat brain during fetal and postnatal development, detecting $1 B 236$ mRNA by RNA blotting and assaying $1 \mathrm{~B} 236$ protein by electroblotting and radioimmunoassay with antibodies against synthetic peptides. By both indices, expression of the $1 \mathrm{~B} 236$ gene products is found to be a relatively late event in neuronal development. 1B236 mRNA is first detectable in extracts of whole rat brain at Postnatal Day 5 (PD 5) and increases to a maximum concentration at PD 25. In extracts of dissected brain regions, $1 \mathrm{~B} 236 \mathrm{mRNA}$ is first detectable at PD 5 in hindbrain and cerebellum, at PD 9 in midbrain/diencephalon, but not until PD 13 in telencephalon. The appearance of 1 B236 protein follows a very similar time course to that of its mRNA in both whole brain and dissected brain regions, suggesting that the expression of the protein during development is regulated largely by transcription of its mRNA. The pattern of 1 B236 expression was confirmed by immunocytochemical localization of 1 B236 protein: Immunoreactive material can be detected first in spinal cord at PD 3-PD 5 and then appears in progressively more rostral brain regions in increasingly older animals. Several brain regions, however, that do not contain 1 B236 immunoreactivity in the adult, such as optic nerve and somatic efferent cranial nerve nuclei, show transient expression of $1 \mathrm{~B} 236$ during postnatal development. The postnatal expression of $1 \mathrm{B236}$ indicates that this protein is a marker for the terminal differentiation of particular neurons and suggests that the $1 \mathrm{B236}$ protein probably mediates functions specific to the adult nervous system.

We have estimated that there are up to 30,000 different proteins expressed in the mammalian brain, most of which are exclusive to the brain and other components of the nervous system (Milner and Sutcliffe, 1983). To study the proteins encoded by these mRNAs we have developed an experimental strategy involving recombinant DNA techniques and antibodies against synthetic peptides (Sutcliffe et al., 1983a). The clone p1B236 was selected for study from a cDNA library generated from adult rat brain

\footnotetext{
Received May 22, 1985; revised July 29, 1985; accepted July 31, 1985.

We acknowledge the expert technical assistance of Lynne Randolph and Patria Danielson. We thank Greg Sutcliffe, Bernard Malfroy, Cary Lai, and Hartwig Schmale for frequent discussions and advice. This work was supported in part by NIH Grants NS 20728 and GM 32355, NIAAA Alcohol Research Center Grant AA 06420, and McNeil Laboratories. Dominique Lenoir is supported by a grant from the Swiss National Foundation. This is publication BCR-3880 from the Research Institute of Scripps Clinic.

Correspondence should be addressed to Dr. Robert J. Milner, Scripps Clinic, BCR1, 10666 N. Torrey Pines Road, La Jolla, CA 92037.
}

Copyright (C) 1986 Society for Neuroscience $0270-6474 / 86 / 020522-09 \$ 02.00 / 0$ cytoplasmic poly (A) ${ }^{+}$RNA because it hybridized to a mRNA that was present in brain but was undetectable in liver or kidney (Sutcliffe et al., 1983a). The nucleotide sequence of p1B236 provided the novel 318-amino acid carboxy terminal sequence of the corresponding protein (1B236). To detect this protein in brain, antisera were raised in rabbits against three synthetic peptides, P5-P7, which corresponded to nonoverlapping regions of the protein sequence.

We have used the anti-peptide antibodies to definc the molecular forms of 1B236 in rat brain extracts (Malfroy et al., 1985; Sutcliffe et al., 1983b). The most abundant form is of high molecular weight (ca. 100,000), is glycosylated, requires detergent for solubilization, and is probably membrane-bound. In addition, low-molccular-wcight spccics, corresponding to peptides P5 and P7, are detectable in brain extracts prepared under conditions that prevent proteolysis. In immunocytochemical analyses of brain sections, antibodies against each peptide specifically detected immunoreactive material in a population of neuronal cells and fibers distributed throughout the rat CNS and distinct from any other immunocytochemically defined system (Bloom et al., 1985; Sutcliffe et al., 1983a). Immunoreactivity was particularly prominent in hindbrain, especially spinal cord and cerebellum, and in forebrain structures such as hippocampus, cingulate and somatosensory cortex, and within the olfactory system. We hope to approach the function of molecules such as $1 \mathrm{~B} 236$ by gaining clues from their various properties, for example, by analyzing sequence information, defining the molecular forms of the protein and their biochemical properties, and determining their neuroanatomical and subcellular distribution. Similarly, definition of the temporal and spatial expression of the 1 B236 gene during development may place limits on the types of functions that its products may mediate.

We report here the course of 1B236 gene expression during the development of the rat central nervous system. Both 1B236 mRNA and protein are only detectable in the postnatal brain, first in the hindbrain and then in progessively more rostral regions with increasing age. The postnatal expression of 1 B236 suggests that the protein mediates functions of the adult nervous system and is therefore a marker for terminal neuronal differentiation. As such it appears particularly useful for revealing the dynamics of the developing cell populations in which it is expressed.

\section{Materials and Methods}

Timed pregnant Sprague-Dawley rats (Charles River) provided a source of fetal and neonatal brains of precise gestational and chronological ages. Two series of animals were used. In the first series, whole brains were taken from animals on embryonic days (ED) 14, 16, 18, and 20 and on postnatal days (PD) 1, 5, 10,15, 20, 25, and 30. For the second series of animals, brains were taken on alternate days from PD 3 to PD 29 and dissected into telencephalon (including neocortex, striatum, hippocampus, and olfactory bulb), midbrain/diencephalon (including thal- 
amus, hypothalamus, superior and inferior colliculi, and midbrain tegmentum), hindbrain (including pons and medulla oblongata), and cerebellum. Telencephalon was dissected from the brains by vertical cuts, centered on the midline and angled parallel to the anterior surface of the superior colliculus. The remainder of the brain was separated into midbrain/diencephalon and hindbrain by a cut in the coronal plane at the interface between inferior colliculus and cerebellum. Cerebellum was then dissected from hindbrain to provide a fourth brain region. At each age, some brains were extracted for RNA while others were extracted for protein.

\section{Extraction and analysis of $R N A$}

Cytoplasmic RNA was isolated from fresh brains by extraction with phenol/chloroform/isoamylalcohol (50:50:1) (Schibler et al., 1980) and enriched for poly(A) ${ }^{+}$RNA by passage over oligo (dT)-cellulose (Aviv and Leder, 1972). The RNA concentration of each preparation was determined by measuring absorbance at $260 \mathrm{~nm}$ : A $38 \mu \mathrm{g} / \mathrm{ml}$ solution was assumed to have an absorbance of 1.0 . For initial quantitation of 1 B236 mRNA, the "slot blotting" technique was used (Brown et al., 1983): Several serial twofold dilutions of each poly(A)+ RNA preparation were applied in a pattern of slots to a single sheet of nitrocellulose. Alternatively, $2 \mu \mathrm{g}$ of each poly(A) ${ }^{+}$RNA extract was fractionated by electrophoresis on $1.5 \%$ agarose gels in the presence of $1 \mathrm{~m}$ formaldehyde (Rave et al., 1979) and transferred to nitrocellulose (Thomas, 1980). Blots of both types were prehybridized at $42^{\circ} \mathrm{C}$ in $50 \%$ formamide, 0.75 $\mathrm{M} \mathrm{NaCl}, 25 \mathrm{~mm}$ 1,4-piperazinediethylenesulfonic acid (PIPES) (pH 6.8), $0.2 \%$ SDS, $25 \mathrm{~mm}$ EDTA, $100 \mu \mathrm{g} / \mathrm{ml}$ salmon sperm DNA, $100 \mu \mathrm{g} / \mathrm{ml}$ yeast tRNA, and $5 \times$ Denhardt's solution (Denhardt, 1966) for at least $4 \mathrm{hr}$ and hybridized with ${ }^{32} \mathrm{P}$-labeled probes for $20 \mathrm{hr}$ in the same solution but with $1 \times$ Denhardt's. The radioactive probes were generated by labeling the appropriate cDNA clones with ${ }^{32} \mathrm{P}$ by nick translation (Rigby et al., 1977) to specific activities of $2-7 \times 10^{-8} \mathrm{cpm} / \mu \mathrm{g}$. Blots were washed twice in $2 \times$ standard saline citrate (SSC) $/ 0.2 \%$ SDS at $42^{\circ} \mathrm{C}$ for $1 \mathrm{hr}$ and once in $0.2 \times \mathrm{SSC} / 0.2 \%$ SDS for $45 \mathrm{~min}$ at $60^{\circ} \mathrm{C}$. They were exposed to Kodak XRP- 5 film at $-70^{\circ} \mathrm{C}$ with Cronex Lightening Plus intensifying screens for 1-14 d. Films to be scanned by densitometry were preflashed to obtain a linear autoradiographic intensity.

\section{Extraction and analysis of proteins}

Brain samples were homogenized (Polytron, Brinkmann) in 4 vol (wt/ vol) ice-cold $10 \%$ sucrose. Aliquots of these homogenates were frozen immediately and used for determination of total brain protein. Other aliquots were extracted with $2 \%$ SDS, $5 \% 2$-mercaptoethanol in $50 \mathrm{~mm}$ Tris- $\mathrm{HCl}, \mathrm{pH} 6.8$, at $100^{\circ} \mathrm{C}$ for $5 \mathrm{~min}$, cleared by centrifugation for 5 min in a microfuge, and stored at $-20^{\circ} \mathrm{C}$. SDS protein extracts (approximately $50 \mu \mathrm{g}$ /lane) were separated by electrophoresis on $7.5 \%$ polyacrylamide gels (Laemmli, 1970) and transferred electrophoretically to nitrocellulose (Towbin et al., 1979). Blots were pretreated for $1 \mathrm{hr}$ in $3 \%$ gelatin in $20 \mathrm{~mm}$ Tris- $\mathrm{HCl}$ ( $\mathrm{pH} 7.5$ ), $0.5 \mathrm{M} \mathrm{NaCl}$ with $0.05 \%$ Tween20 and incubated overnight at room temperature in the same solution with $1 \%$ gelatin containing a 1:500 dilution of antiserum against 1B236 synthetic peptides P5, P6, or P7 obtained as described previously (Sutcliffe et al., 1983a). Immunoreactivity was detected with goat-antirabbit immunoglobulin conjugated in HRP and developed with hydrogen peroxide and 4-chloronaphthol. In parallel experiments, the reaction was blocked by preabsorption of the antiserum with the appropriate peptide.

Brains were also extracted with $2 \% \mathrm{NP} 40$ in $10 \mathrm{~mm}$ Tris- $\mathrm{HCl}(\mathrm{pH}$ 7.4), $150 \mathrm{~mm} \mathrm{NaCl}$, at $4^{\circ} \mathrm{C}$, in order to solubilize the high-molecular form of the protein $1 \mathrm{~B} 236$, centrifuged to remove insoluble material, and assayed by radioimmunoassay (RIA) (Malfroy et al., 1985).

\section{Immunohistochemistry}

Animals of selected postnatal ages were prepared for immunohistochemical staining by transcardial perfusion with freshly depolymerized $4 \%$ paraformaldehyde in $0.15 \mathrm{~m}$ phosphate buffer $(\mathrm{pH} 7.4)$ for $5 \mathrm{~min}$, followed by removal of the brain, and immersion fixation of frontal or sagittal slabs 3-5 mm thick for an additional 3-8 hr. Tissue slabs were rinsed in graded sucrose solutions $(12,16$, and $18 \%$ in phosphate buffered saline) and stored in $18 \%$ sucrose until sectioning in frontal or sagittal planes by cryomicrotomy at $20-50 \mu \mathrm{m}$. 1B236 immunoreactivity was detected in free-floating sections by two-step indirect peroxidase methods as described previously (Bloom et al., 1985).
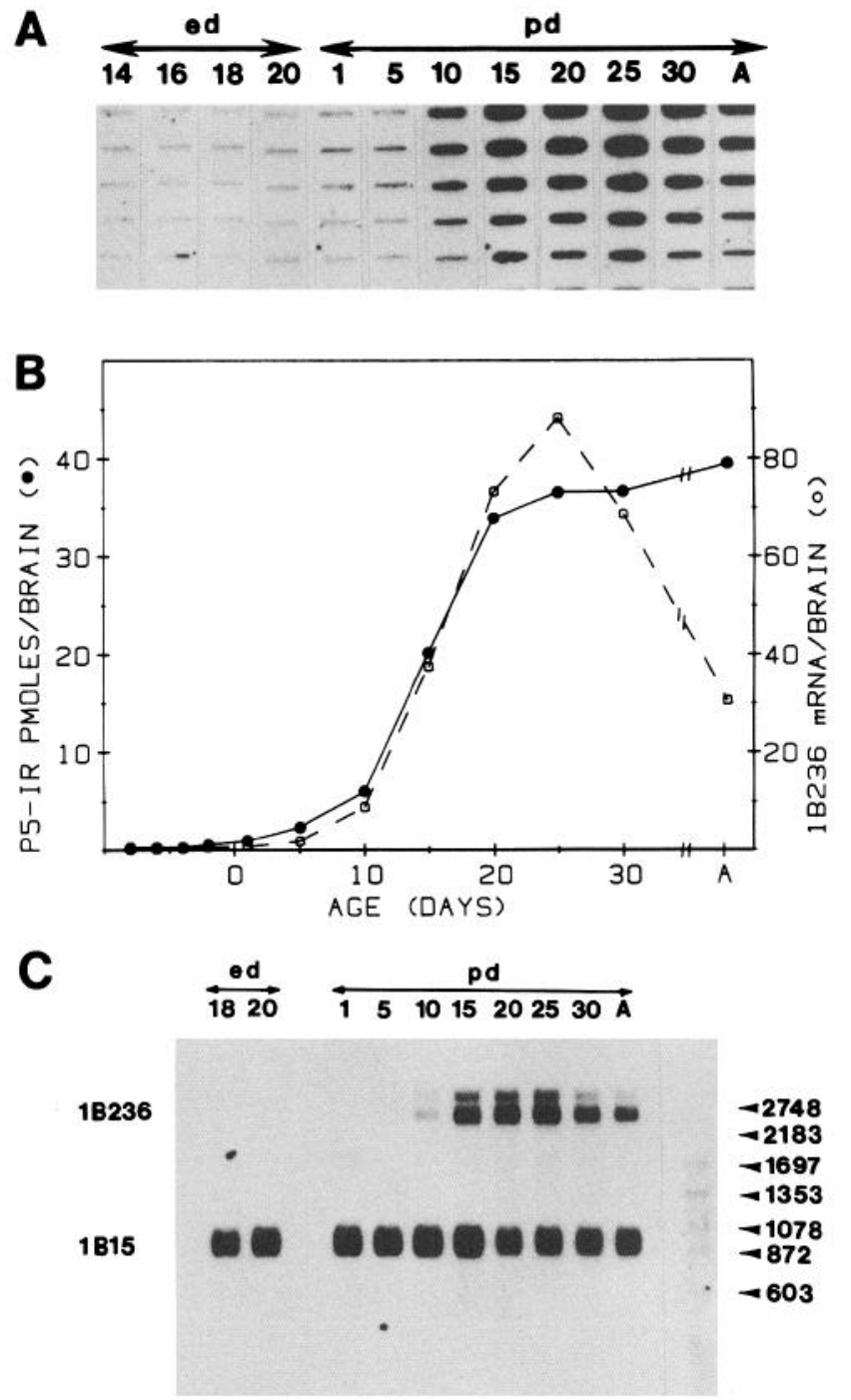

Figure 1. Expression of 1B236 mRNA and protein during brain development. $A$, "Slot-blot" analysis of 1B236 mRNA. Aliquots $(2 \mu \mathrm{g})$ of poly(A) ${ }^{+}$RNA extracted from animals of the indicated embryonic $(e d)$ and postnatal $(p d)$ ages and from adult $(A)$, were serially diluted, applied to nitrocellulose, and hybridized with ${ }^{32} \mathrm{P}$-labeled p1B236. The autoradiograph of the blot is shown. B, Quantitation of 1B236 mRNA and protein. The autoradiographic intensities of the slot-blot shown above were determined by densitometric scanning and are expressed in arbitrary units of autoradiographic intensity. The data shown represent the values for one set of RNA dilutions; similar results were obtained for each set of dilutions. $C$, Northern blot analysis of 1B236 mRNA. Aliquots $(2 \mu \mathrm{g})$ of poly $(\mathrm{A})^{+}$RNA extracted from rat brains of the indicated embryonic $(e d)$ and postnatal $(p d)$ ages and from adult $(A)$ were separated by electrophoresis, blotted to nitrocellulose, and hybridized with ${ }^{32} \mathrm{P}$-labeled p1B236 and p1B15. The autoradiograph of this blot is shown, and the 1B236 and 1B15 mRNA bands are indicated. At the right are shown the positions of DNA size markers.

\section{Results}

\section{Ontogeny of $1 B 236$ in whole brain}

For the first part of the study, rats from ED 14 to PD 30 were used for extraction of whole brain cytoplasmic RNA. In parallel, whole brains from pups of similar ages were homogenized and extracted for protein analysis: Aliquots of the homogenates were used for determination of total brain protein. At ED 14, the whole head was extracted; at all other ages, whole brains were 

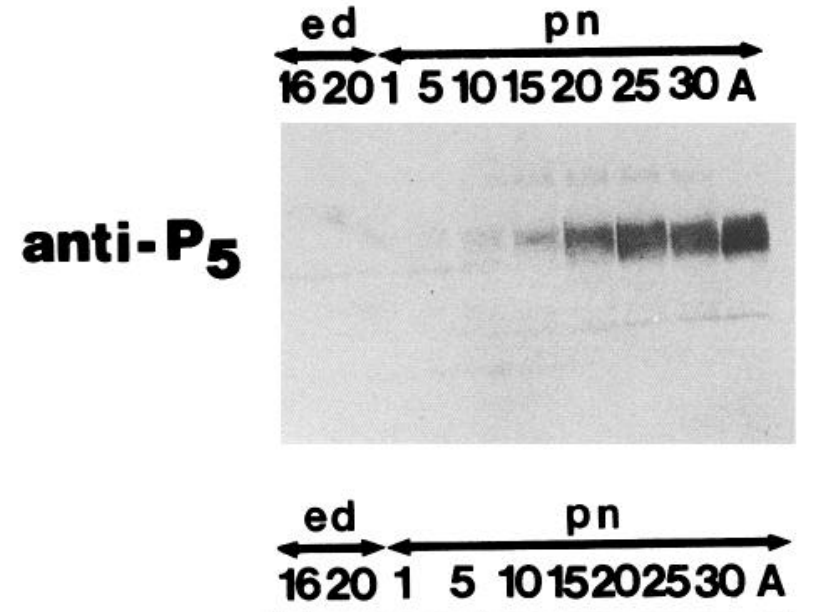

anti-P6
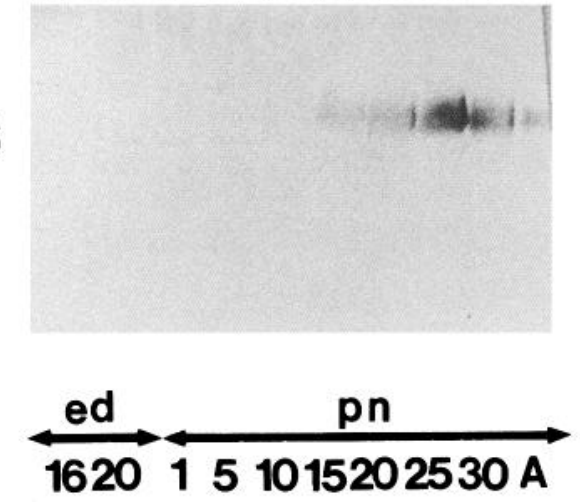

\section{anti-P $\mathbf{7}$}

Figure 2. Developmental expression of $1 \mathrm{~B} 236$ protein detected by immuno (Western) blotting. Aliquots of SDS extracts of rat brains at the indicated embryonic $(e d)$ and postnatal $(p n)$ ages and adult $(A)$ were separated by electrophoresis and electroblotted to nitrocellulose. Identical blots were incubated in parallel with antibodies against 1B236 peptide P5, P6, or P7, and bound antibody was visualized with goatantirabbit immunoglobulin conjugated to horseradish peroxidase.

extracted. Earlier embryos were not pursued because of difficulties of dissection and the small amounts of tissue. Increases in brain wet weight, total brain protein, and extractable, whole brain poly (A) + RNA follow an approximately parallel time course throughout development. In adults, however, there is a drop in poly $(\mathrm{A})^{+}$RNA levels while protein and brain weight increase slightly.

The amount of 1B236 mRNA in the poly $(\mathrm{A})^{+}$RNA preparations from each age was quantitated by "slot blotting" (Fig. $1 A)$ : The autoradiographic intensities of the different RNA samples and their dilutions were compared directly and quantitated by densitometry (Fig. 1B). The 1B236 mRNA is detected only in the postnatal brain, faintly appearing at PD 1 and PD 5 and clearly increasing by PD 10. The amount of 1B236 mRNA increases up to PD 25 and then decreases with age, showing lower values in PD 30 and adult brains. To examine the expression of 1B236 mRNA in more detail, aliquots $(2 \mu \mathrm{g})$ of cytoplasmic poly $(\mathrm{A})^{+}$RNA from each age were fractionated by electrophoresis, blotted to nitrocellulose, and hybridized with ${ }^{32}$ P-labeled plasmid p1B236 ("Northern" blotting). In the Northern blot (Fig. 1C), 1B236 mRNA is faintly detectable at PD 5 and clearly demonstrable by PD 10, as shown by the slot blot experiment. In addition, two different bands can clearly be detected for 1B236 at each age (Fig. 1C), suggesting the existence of at least two different 1B236 mRNAs, approximately 2.5 and 3.2 kilobases $(\mathrm{kb})$ in length. We had previously estimated the major 1B236 mRNA to be 1700 nucleotides long (Sutcliffe et al., 1983a). Subsequent experiments, including those described here (Fig. $1 C$ ), demonstrate that the major mRNA is $2500 \mathrm{nu}-$ cleotides long and that there is also a minor mRNA component, approximately 3200 nucleotides long. Recent evidence also indicates that there is a single gene for 1B236 in the rat genome and that at least two different 1B236 mRNAs may be derived from this gene by differential splicing (C. Lai, K. A. Nave, J. G. Sutcliffe, and R. J. Milner, unpublished results).

The RNA blot was simultaneously hybridized with the ${ }^{32} \mathrm{P}-$ labeled plasmid p1B15: This clone corresponds to an mRNA that occurs in approximately equal amounts in most rat tissues (Milner and Sutcliffe, 1983; Sutcliffe et al., 1983b) and is useful as an internal control for normalizing mRNA concentration and detecting degradation during RNA isolation. The 1B15 mRNA is expressed with a similar abundance throughout development, showing less than a twofold variation in autoradiographic intensity from ED 14 to adult, as determined by densitometric scanning of the original $\mathrm{x}$-ray film (not shown). The variation in 1B236 mRNA abundance at different ages is therefore not due to RNA degradation or variations in the amounts of sample loaded. Furthermore, the marked differences in the patterns of expression of 1B236 mRNA and 1B15 mRNA are still obtained whether the autoradiographic intensity data are expressed per brain, per gram brain wet weight, or per milligram brain protein (not shown), indicating that the increase in total 1B236 mRNA expression between PD 5 and PD 25 is not simply due to an increase in brain size. Both the 3.2 and $2.5 \mathrm{~kb} 1 \mathrm{~B} 236 \mathrm{mRNA}$ bands display a similar time course of expression, although it is interesting to note that the ratio of the intensities of the two 1 B236 bands $(3.2 / 2.5 \mathrm{~kb})$ decreases with age from 0.67 at PD 10 to 0.32 in the adult, suggesting that there may be a difference in the expression of these two mRNAs during development.

To compare the increases in 1B236 mRNA and protein in whole brain at different developmental times, the amounts of 1 B236 protein in NP40 extracts of brain were determined by RIA and plotted together with the quantitation of $1 \mathrm{~B} 236 \mathrm{mRNA}$ (Fig. $1 B$ ). There is a close correlation between the time of appearance and the increases in the concentrations of both 1B236 mRNA and protein throughout development until PD 25. After this time, the whole brain content of 1B236 mRNA decreases, while the amount of $1 \mathrm{~B} 236$ protein remains approximately constant.

Under the conditions of NP40 extraction used here, the RIA using P5 antibodies measures the concentration of the 100,000 $\mathrm{Da}$ form of the protein (Malfroy et al., 1985). To confirm the identity of this protein, we analyzed protein extracts of brains at different ages by Western blotting (Fig. 2) using antibodies against the three peptides P5, P6, and P7, corresponding to different regions of the 1B236 polypeptide (Sutcliffe et al., 1983a). Each antibody specifically detects a protein band of approximately $100,000 \mathrm{Da}$, which is the predominant molecular form of the 1B236 protein (Malfroy et al., 1985). In a parallel experiment (not shown), the antibody reaction with the 100,000 $\mathrm{Da}$ band was blocked by preabsorption of the antiserum with the appropriate immunogen peptide, indicating that in each case, the detected molecule is the 1B236 protein. The faint bands observed on the anti-P5 blot other than the 100,000 Da band were not blocked by P5 and were not detected by anti-P6 or anti-P7 antibodies, suggesting that these were not products of 
postnatal day

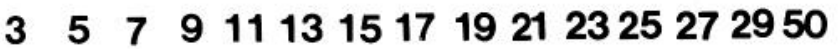

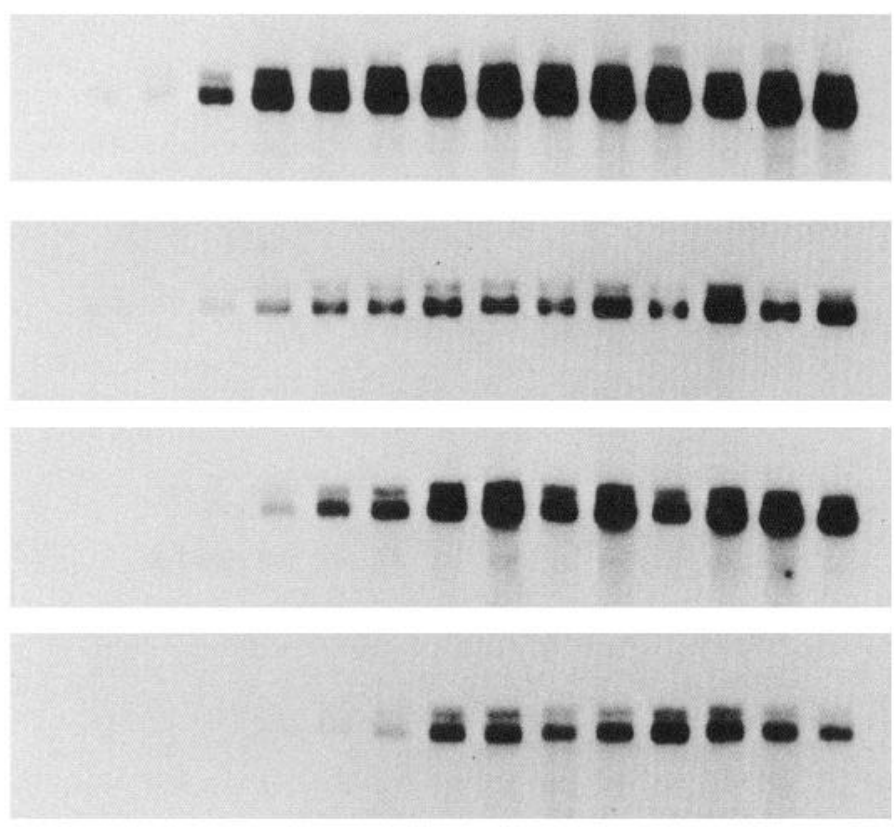

the $1 \mathrm{~B} 236$ mRNA. As indicated by the RIA data, the 100,000 dalton 1B236 protein can be faintly detected at PD 5, clearly by PD 10 and shows increases in concentration at later ages, a similar pattern of appearance to that of its mRNA.

\section{Regional developmental patterns}

These results define the developmental expression of 1B236 in the whole brain. Development of the brain, however, does not proceed uniformly in all regions. It was of interest, therefore, to have a more defined idea about the expression of 1B236 in different brain areas. As both 1B236 mRNA and protein were shown to appear after birth, we performed Northern and Western blots using extracts of brains excised every other day from PD 3 to PD 29 and dissected into four discrete regions: telencephalon, midbrain/diencephalon, cerebellum, and hindbrain. These data provide a more detailed picture of 1B236 expression. Expression of 1B236 mRNA proceeds in a caudal to rostral direction: It can first be clearly detected at PD 5 in hindbrain and cerebellum, at PD 9 in midbrain/diencephalon, and at PD 13 in telecephalon (Fig. 3) and shows pronounced increases in abundance beginning at these ages in each region. Heavily overexposed autoradiographs of the same blots show very faintly detectable 1B236 mRNA bands 2-4 d earlier than these times. The differences of intensity observed from one day to another at older ages are due to small variations in the amounts of sample loaded, as shown by hybridization of the same blots with p1B15 (data not shown).

All of the RNA blotting studies have used poly(A)+ RNA prepared by a single passage and elution from oligo (dT)-cellulose. Such preparations typically contain $30-50 \%$ mRNA, the remainder being rRNA. To ensure that the apparent differences in $1 \mathrm{~B} 236 \mathrm{mRNA}$ were not due to different efficiencies in poly(A) ${ }^{+}$ RNA preparation, we subjected the samples of poly $(\mathrm{A})^{+}$RNA from telencephalon to a second passage and elution from oligo (dT)-cellulose and analyzed these preparations on a Northern blot that was hybridized with both p1B236 and p1B15. The recovery of poly $(\mathrm{A})^{+}$RNA from the oligo (dT) columns was 30-

\section{hindbrain}

\author{
cerebellum
}

midbrain

telencephalon
Figure 3. Developmental expression of 1B236 mRNA in different brain regions. Aliquots $(2 \mu \mathrm{g})$ of poly(A)+ RNA extracted from hindbrain, cerebellum, midbrain, and telencephalon of animals at the indicated postnatal ages were separated by electrophoresis, blotted to nitrocellulose, and hybridized with ${ }^{32} \mathrm{P}$-labeled 1 B236.
$40 \%$ of the amount loaded. The results were indistinguishable from those shown in Figure 3, demonstrating that the data obtained with the original RNA preparations accurately represent the expression of $1 \mathrm{~B} 236 \mathrm{mRNA}$.

The Western blots of the regional brain extracts using antiP5 antibody (Fig. 4) show that the 1B236 protein has a generally similar pattern of expression in brain regions as its mRNA, although there are some differences in detail. In hindbrain, the 1B236 protein band can be detected faintly from PD 3 onward, with a marked increase in intensity after PD 9. In cerebellum, $1 \mathrm{~B} 236$ protein can also be detected from PD 3 onward, but the band increases in intensity only from PD 15 onward, a later age than is shown by the increase in expression of 1B236 mRNA in cerebellum at PD 9-PD 11. In midbrain the 1 B236 protein band increases in intensity from PD 11 onward and in telencephalon from PD 15 onward, in each case, $2 \mathrm{~d}$ after the increase in expression of 1B236 mRNA. In both these regions, however, 1B236 protein can be faintly detected at earlier times: in midbrain from PD 5 and in telencephalon from PD 11. As suggested by the immunocytochemistry studies described below, these differences in the expression of 1B236 mRNA and protein probably reflect the appearance of 1 B236 immunoreactive fibers, originating from more caudal areas, in these regions before the synthesis of 1B236 mRNA by intrinsic cell bodies. In general, 1B236 protein expression closely follows its mRNA expression, temporally and spatially. The abundance of both 1B236 mRNA and protein appears to be generally higher in hindbrain and midbrain than in cerebellum or telencephalon, as indicated from studies of their distribution in regions of the adult brain (Sutcliffe et al., 1983a; B. Malfroy, C. Bakhit, D. Lenoir, and R. J. Milner, unpublished observations).

\section{Immunocytochemical analysis of 1 B236 development}

The immunocytochemical distribution of $1 \mathrm{~B} 236$ was assessed at 2-3 d intervals from PD 3 to PD 24. The times of appearance of 1B236 immunoreactive cell bodies and fibers in different brain regions are summarized in Table 1 . Immunoreactive neu- 
postnatal day

\section{$\begin{array}{lllll}3 & 7 & 9 & 11 & 13151719 \\ 212325272950\end{array}$}

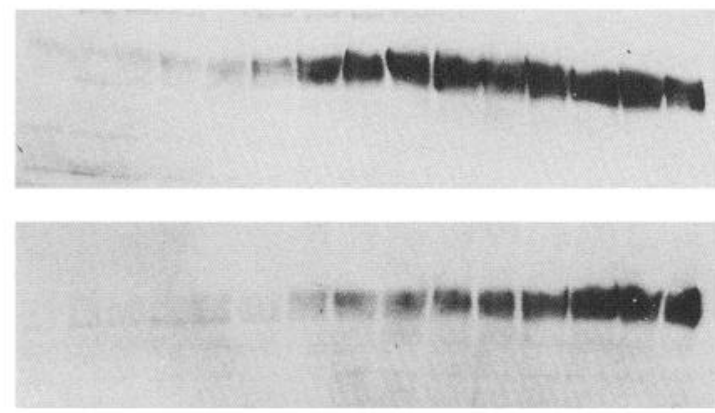

\section{hindbra in}

cerebellum

midbrain

Figure 4. Developmental expression of $1 \mathrm{~B} 236$ protein in different brain regions. Aliquots of SDS extracts of hindbrain, cerebellum, midbrain, and telecephalon were separated by electrophoresis, electroblotted to nitrocellulose, and assayed for 1B236 protein as described for Fig. 2, using antisera to 1B236 peptide P5.
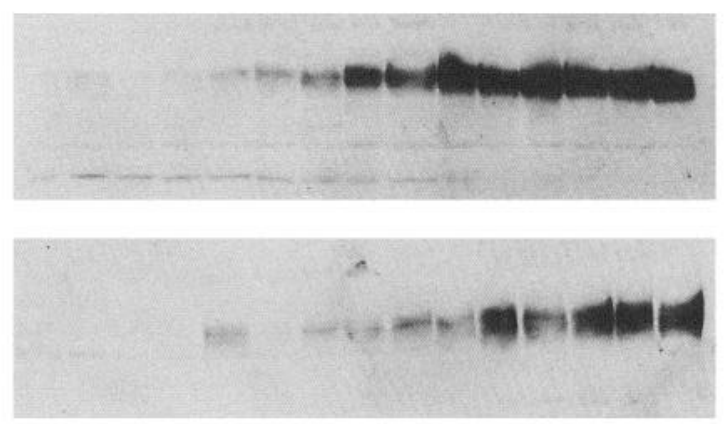

telencephalon rites were first observable within the spinal cord and brain stem at PD 5 and were thereafter detected at progressively higher levels within the developing neuroaxis, reaching detection in the presumptive somatosensory cortex at PD 11. The development of the characteristic radial fiber patterns observed in the adult cortex (Bloom et al., 1985; Sutcliffe et al., 1983) occurs between PD 11 and PD 24 (Fig. 5).

Within the forebrain in general, all fiber and cell systems seen in the adult are easily detectable by PD 19. Prior to PD 19, some systems that are not immunoreactive in the adult express 1B236 immunoreactivity transiently, such as the optic nerves and tract (Fig. 5), as well as nerve fibers entering the lateral geniculate. Transient 1B236 expression (PD 9-PD 17) was also seen in cranial motor neurons and their efferent tracts, as well as in the pyramidal tract. Following PD 19, neurites containing $1 \mathrm{~B} 236$ as well as distinctly immunoreactive cell bodies are close approximations of the adult pattern. Indeed, analysis of cell bodies in the pups at PD 20-PD 29 is possible without any colchicine pretreatment and confirms the distributions reported earlier (Bloom et al., 1985).

At least three classes of morphologically distinct immunoreactive perikarya could be recognized in the developing brain:

1. "Conventional neurons" with highly reactive, diffuse cytoplasmic binding of the antibody, and prominent multipolar cytoplasmic extensions that increase with maturity and can be interpreted as dendrites; such neurons could be recognized at the lateral limits of the germinal zones of the PD 5 spinal cord, and deep within the subcortical fiber zones of the PD 7 parietal cortex, and in many other regions.

2. "Hairy" cells, in which the nonimmunoreactive, toluidine blue positive nucleus could be seen to be surrounded by thin strands of intracellular material that generally appeared to be streaming in a direction parallel to the long axis of the cell; such hairy cells were readily discernible in all regions of the developing rat brain, frequently near neurons with more conventional morphology.
3. "Clumpy" cells, with large clumps of immunoreactive material within the perikaryon, but not within the dendrites, were recognized in spinal cord, mesencephalic, and thalamic nuclei with intensely immunoreactive afferent or efferent fiber bundles; these cells were seen as early as PD 5-PD 7, generally mixed with conventional and "hairy" cell types.

Detailed region-by-region descriptions of changes in cell morphology and fiber ingrowth and terminal field modification are in progress and will be reported separately when the gene products of the different 1B236 mRNAs are more fully discriminable. However, the expression of 1B236 P5 immunoreactivity allows us to document the rapid ingrowth of fibers, as from reticular formation and spinal cord into the vestibular and cochlear nerve nuclei and the deep cerebellar nuclei, and from the subcortical fiber zones into the basal ganglia and internal capsule. In other terminal field regions, such as hippocampus, immunoreactive fibers could be traced from medial septal nuclei neurons into the fimbria as early as PD 5, but such fibers do not immediately exhibit immunoreactivity within the CA3 and CA4 subfields until PD 15.

\section{Discussion}

In this study, we have followed the developmental expression of the brain specific gene $1 \mathrm{~B} 236$ by determining in parallel the levels of its mRNA and protein and the cellular localization of the protein. The results show that 1B236 is expressed first in spinal cord and hindbrain at PD 3-PD 5 and then in more rostral brain regions with increasing age, following the general caudal to rostral developmental pattern of the brain, finally appearing in cortex at PD 11-PD 13.

The expression of the $1 \mathrm{~B} 236$ protein closely follows the expression of its mRNA: Thus, the increase in 1B236 mRNA expression, in both whole brain and dissected brain regions, is followed by a similarly rapid increase in amounts of its major translation product, the high-molecular-weight 1B236 protein, detected by either RIA or immunoblotting. Most simply, these 
Table 1. Immunocytochemical detection of $1 \mathrm{B236}$ in cells and fibers in the developing rat brain

\begin{tabular}{|c|c|c|c|c|c|c|c|c|c|c|}
\hline Brain region & PD 5 & PD 7 & PD 9 & PD 11 & PD 13 & PD 15 & PD 17 & PD 19 & PD 24 & A \\
\hline \multicolumn{11}{|l|}{ Spinal cord } \\
\hline Dorsal horn & $\mathrm{C}, \mathrm{F}$ & $\mathrm{C}, \mathrm{F}$ & $\mathrm{C}, \mathrm{F}$ & $\mathrm{C}, \mathrm{F}$ & $\mathrm{C}, \mathrm{F}$ & $\mathrm{C}, \mathrm{F}$ & $\mathrm{F}$ & $\mathbf{F}$ & $\mathrm{F}$ & $\mathrm{F}$ \\
\hline Central gray & & F & $\mathbf{F}$ & $\mathrm{F}$ & $\mathrm{F}$ & $\mathrm{F}$ & $\mathrm{F}$ & $\mathrm{F}$ & $\mathbf{F}$ & $\mathbf{F}$ \\
\hline \multicolumn{11}{|l|}{ Hindbrain } \\
\hline Dorsal cochlear nucleus & & $\mathrm{C}, \mathrm{F}$ & $\mathrm{C}, \mathrm{F}$ & $\mathrm{C}, \mathrm{F}$ & $\mathrm{C}, \mathrm{F}$ & $\mathrm{C}, \mathrm{F}$ & $\mathrm{C}, \mathrm{F}$ & $\mathrm{C}, \mathrm{F}$ & $\mathrm{F}$ & $\mathrm{F}$ \\
\hline Pyramidal tract & & & F & $\mathrm{F}$ & F & $\mathrm{F}$ & $\mathrm{F}$ & & & \\
\hline Substantia nigra & & & $\mathrm{C}, \mathrm{F}$ & $\mathrm{C}, \mathrm{F}$ & $\mathrm{C}, \mathrm{F}$ & $\mathrm{C}, \mathrm{F}$ & $\mathrm{C}, \mathrm{F}$ & $\mathrm{F}$ & $\mathbf{F}$ & $\mathbf{F}$ \\
\hline Dorsal, pontine raphe & & & & $\mathrm{C}, \mathrm{F}$ & $\mathrm{C}, \mathrm{F}$ & $\mathrm{F}$ & $\mathrm{F}$ & $\mathrm{F}$ & $\mathbf{F}$ & $\mathbf{F}$ \\
\hline Inferior olive & & & & $\mathrm{C}, \mathrm{F}$ & $\mathrm{C}, \mathrm{F}$ & $\mathrm{C}, \mathrm{F}$ & $\mathrm{C}, \mathrm{F}$ & $\mathrm{C}, \mathrm{F}$ & $\mathrm{F}$ & $\mathrm{F}$ \\
\hline Medial trapezoid nucleus & & & & $\mathrm{F}$ & $\mathrm{F}$ & $\mathrm{F}$ & $\mathbf{F}$ & $\mathrm{F}$ & $\mathrm{F}$ & $\mathrm{C}, \mathrm{F}$ \\
\hline Locus coeruleus & & & & $\mathrm{F}$ & $\mathrm{F}$ & $\mathrm{F}$ & $\mathbf{F}$ & $\mathrm{F}$ & $\mathrm{F}$ & $\mathbf{F}$ \\
\hline \multicolumn{11}{|l|}{ Cerebellum } \\
\hline Superior CB peduncle & & F & F & F & $\mathbf{F}$ & F & $\mathrm{F}$ & $\mathrm{F}$ & $\mathbf{F}$ & $\mathrm{F}$ \\
\hline Deep CB nuclei & & & & $\mathrm{C}, \mathrm{F}$ & $\mathrm{C}, \mathrm{F}$ & $\mathrm{C}, \mathrm{F}$ & $\mathbf{F}$ & $\mathrm{F}$ & $\mathrm{F}$ & $\mathrm{F}$ \\
\hline Granule cell layer & & & & $\mathrm{F}$ & $\mathrm{F}$ & $\mathrm{F}$ & $\mathbf{F}$ & $\mathrm{F}$ & $\mathbf{F}$ & $\mathrm{F}$ \\
\hline Molecular layer & & & & & & & $\mathbf{F}$ & $\mathrm{F}$ & $\mathbf{F}$ & $\mathrm{F}$ \\
\hline \multicolumn{11}{|l|}{ Midbrain } \\
\hline Thalamus (DM, VL, VPL) & $\mathbf{F}$ & $\mathrm{F}$ & $\mathrm{C}, \mathrm{F}$ & $\mathrm{C}, \mathrm{F}$ & $\mathrm{C}, \mathrm{F}$ & $\mathrm{C}, \mathrm{F}$ & $\mathrm{C}, \mathrm{F}$ & $\mathrm{C}, \mathrm{F}$ & $\mathbf{F}$ & $\mathrm{F}$ \\
\hline Posterior commissure & & & $\mathrm{C}, \mathrm{F}$ & $\mathrm{C}, \mathrm{F}$ & $\mathrm{C}, \mathrm{F}$ & $\mathrm{C}, \mathrm{F}$ & $\mathrm{F}$ & F & $\mathbf{F}$ & $\mathrm{F}$ \\
\hline Zona incerta & & & $\mathrm{F}$ & F & $\mathbf{F}$ & $\mathrm{F}$ & $\mathrm{C}, \mathrm{F}$ & $\mathrm{C}, \mathrm{F}$ & $\mathbf{F}$ & $\mathrm{F}$ \\
\hline Optic nerve & & & $\mathrm{F}$ & $\mathrm{F}$ & $\mathrm{F}$ & $\mathrm{F}$ & $\mathrm{F}$ & $\mathrm{F}$ & & \\
\hline Optic tract & & & $\mathbf{F}$ & $\mathrm{F}$ & $\mathrm{F}$ & $\mathrm{F}$ & $\mathbf{F}$ & $\mathrm{F}$ & & \\
\hline
\end{tabular}

\section{Telecephalon}

Olfactory bulb

Germinal zone

Lateral olfactory tract

Internal plexiform layer

External plexiform layer

Subcortex white matter

Fimbria

Olfactory tubercle

Primary olfactory cortex

Caudate/putamen

Parietal cortex

Lateral septal nucleus

Cingulate gyrus

Subiculum

Hippocampus (CA3, CA1)

Amygdala

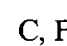

The appearance of 1B236 immunoreactivity, detected by antibody against P5, is documented for each of the listed brain regions at the indicated postnatal dates. The notation of Palkovits (1984) is used to indicate the presence of stained cells $(C)$ or fibers $(F)$; no entry indicates that no $1 \mathrm{~B} 236$ immunoreactivity was observed in that region at that date. 

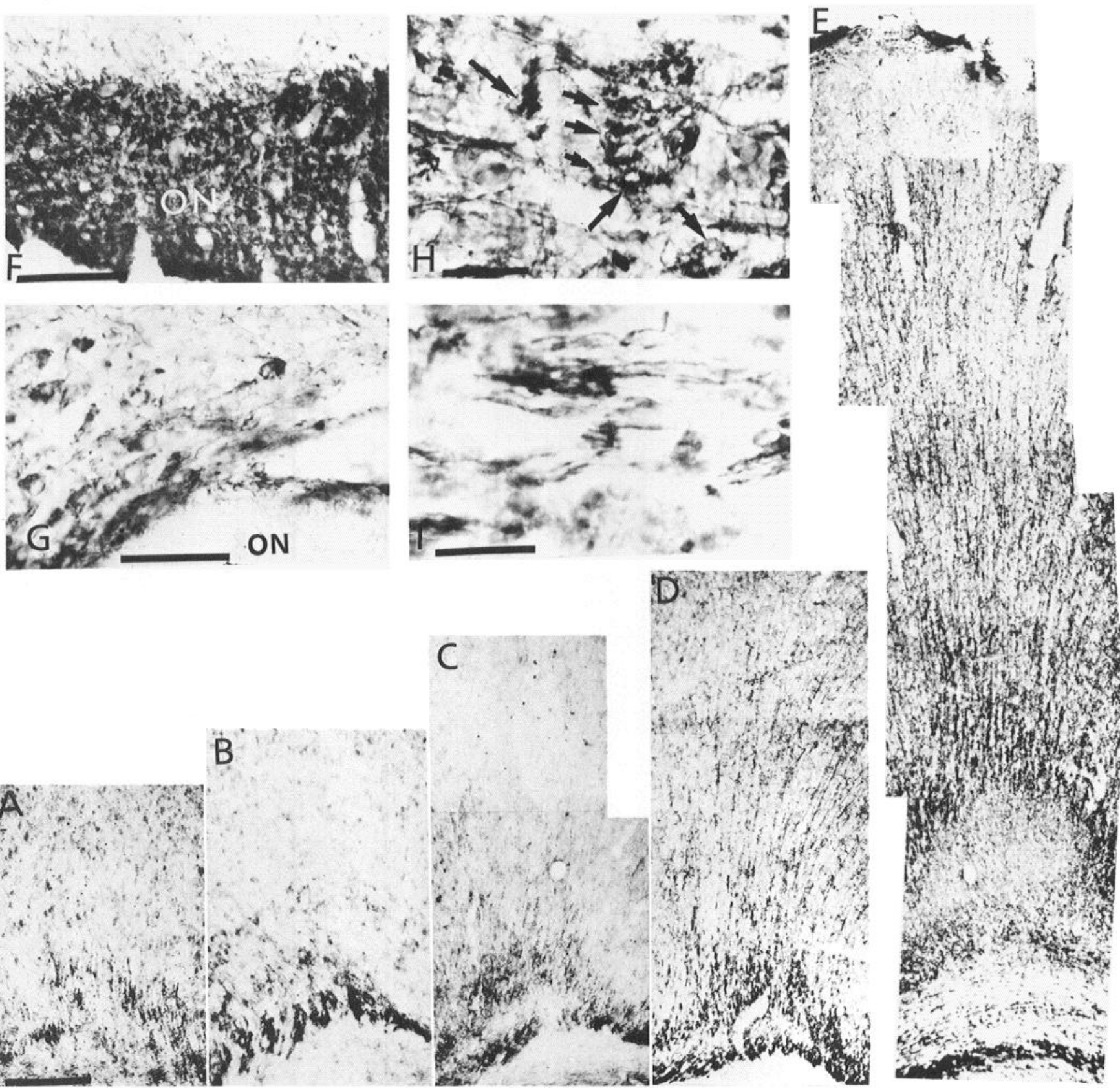

Figure 5. Immunocytochemical reactivity during postnatal development. $A-E$ indicate the vertical progression of immunoreactive neurons and processes within the somatosensory cortex in frontal sections taken at PD $11(A)$, PD $13(B)$, PD $15(C)$, PD $17(D)$, or PD $24(E)$. No immunoreactive elements are detectable before PD 11, when the earliest observed immunoreactive structures are found within and just superficial to the subcortical boundary. Thick processes within the primitive external capsule and the deeper layers of the cortical mantle then extend progressively to more and more superficial laminae as the cortex expands and matures, with immunoreactive radial neurites reaching the adult configuration by PD 24 , when tangential fibers in lamina I can be observed. $F$ and $G$ illustrate the transient expression of 1B236 immunoreactive material detected within the optic nerves $(O N)$, chiasm, and tract on PD $13(F)$, but undetectable in the adult $(G) . H$ and $I$ illustrate the early appearance of nonconventional forms of immunoreactive perikarya, described in the text: "hairy" or "comet" neurons $(H)$, such as those seen here by PD 5 in the ventral reticular formation, in which long, fibrillar immunoreactive structures emanate from the perikaryonal cytoplasm parallel to the long axis of the neuron; "clumpy cells," such as those seen here at PD 16 in the lateral vestibular nucleus, in which several cells (arrows) within a large cluster exhibit large clumps of very coarse granular immunoreactivity surrounding an unreactive nucleus. Both categories of unconventional cells as well as conventional multipolar neurons are persistent forms that are much more difficult to detect in adult rats without colchicine administration. Calibration bars: $200 \mu \mathrm{m}(A-E) ; 100 \mu \mathrm{m}(F, G)$, and $50 \mu \mathrm{m}(H, I)$.

data suggest that the levels of 1B236 protein are determined by the levels of its mRNA and that therefore the expression of the 1B236 gene during development is probably regulated at the level of transcription. The decrease in 1B236 mRNA expression in later developmental stages and adult, however, is not matched by a decrease in the amounts of 1 B236 protein, suggesting that there may be differences in the turnover of $1 \mathrm{~B} 236$ protein and mRNA.

The increase in the relative amounts of 1B236 mRNA and protein in the postnatal brain could have several explanations. For example, this could reflect increases in the expression of 1B236 in each cell, increases in the number of cells that express 
1B236, or a combination of these. The immunocytochemical localization of 1 B236 in the developing brain, however, clearly demonstrates that increasing numbers of neurons are recruited to $1 \mathrm{~B} 236$ expression and that these cells appear in progressively more rostral regions with increasing age, consistent with the patterns of expression of 1B236 mRNA and protein determined in brain extracts. Furthermore, the immunocytochemical analysis allows us to distinguish between 1B236 protein contained in cell bodies and dendrites, which will also contain 1B236 mRNA, and $1 B 236$ protein in axons, which should not contain mRNA, and may hence explain apparent anomalies between the time of expression of 1B236 mRNA and protein in particular brain regions, such as telencephalon. Similarly, the apparently precocious expression of $1 \mathrm{~B} 236$ in the cerebellum, which is generally considered to be a late-developing structure, before its expression in more rostral areas can be explained by the detection of a transient expression of $1 \mathrm{~B} 236$ protein within the cerebellar "white" matter and deep cerebellar nuclei, which may be included when the small, postnatal cerebella are blunt-dissected from the underlying pons.

In addition, the immunocytochemistry of 1B236 in the developing brain helped clarify the interpretation of the adult patterns of 1 B236 innervation. Thus, we have been able to identify $1 \mathrm{~B} 236$ cell bodies that were not revealed by colchicine treatment in the adult, such as in the raphe nuclei, which may be the source of the fiber innervation of the cerebellum. We have also been able to confirm cell body assignments that were problematic in adults, such as the unusual staining pattern in the adult, which we had tentatively termed "hairy cells" (Bloom et al., 1985).

Neuronal cell division is completed largely before birth in rodents, with the exception of granule cells in the cerebellum, hippocampus and olfactory bulb (Angevine, 1965; Hinds, 1968; Miale and Sidman, 1961). The postnatal expression of 1B236 therefore suggests that it belongs to a class of "late onset" mRNAs, appearing in conjunction with the terminal differentiation of neurons after their last cell division, and it could be viewed as a molecular marker of a mature neuronal population. Hence, $1 \mathrm{~B} 236$ is similar to several other proteins that are expressed predominantly or cntircly during postnatal development, such as Thy-1 (Barclay, 1979), neuron-specific enolase (Marangos et al., 1980), rat nervous system antigen G5 (Akeson et al., 1983), neuronal phosphoproteins synapsin I, protein III, DARPP-32, and $G$ substrate (DeGennaro et al., 1983; Lewis et al., 1983), phospholipid-sensitive $\mathrm{Ca}^{2+}$-dependent kinase (Turner et al., 1984), MIT-23 (Hawkes et al., 1982), tau-microtubule associated proteins (Ginzburg et al., 1982), and $\alpha \beta \beta^{\prime}$-spectrin (Lazarides and Nelson, 1983). These proteins appear to be expressed in the final stage of neuronal maturation, and their expression is consistent with measurements of mRNA complexity during brain development that indicate a burst of new gene expression during the late fetal or early postnatal period (Chaudhari and Hahn, 1983; Kaplan and Finch, 1982). In addition, we have shown that transcription of ID sequences by polymerase III, which may be involved in the regulation of this class of brain genes, occurs during this same time period (Sutcliffe et al., 1984). In contrast, several neurotransmitter systems, which might also be considered to be markers of neuronal differentiation, arise much earlier in development: For example, catecholaminergic and serotonergic neurons (Lauder and Bloom, 1974; Wallace and Lauder, 1983) and endorphin and enkephalin systems (Bayon et al., 1979) can be clearly detected several days before birth in rats.

The postnatal appearance and continued expression of 1B236 in the adult suggests that the 1B236 gene products mediate functions of the adult brain. We have proposed that the 1B236 protein may be cleaved to generate several novel neuropeptides (Sutcliffe et al., 1983a). Preliminary experiments indicate that the small 1B236 peptides that can be detected in the adult brain (Malfroy et al., 1985) appear during development with approximately the same time course as the $100,000 \mathrm{Da} 1 \mathrm{~B} 236$ protein (D. Lenoir, B. Malfroy, and R. J. Milner, unpublished observations). We have also considered, however, other hypotheses for the function of the $1 \mathrm{~B} 236$ protein, particularly that it may be involved in axonal transport, based on its association with synaptic vesicles and its properties characteristic of a membrane-associated protein. In this light, it is intriguing that there are several examples of the expression of 1 B236 in cells or fibers in the developing animal that are not represented in the adult: Perhaps in most neuronal systems 1B236 is required throughout adult life, while in a few systems it is only expressed during the establishment of the innervation during development.

\section{References}

Akeson, R. A., J. S. Rodman, and A. Roberts (1983) Induction of expression of the rat $\mathrm{G} 5$ nervous system antigen occurs postnatally. Dev. Brain Res. 7: 327-336.

Angevine, J., Jr. (1965) Time of neuron origin in the hippocampal region. An autoradiographic study in the mouse. Exp. Brain Res. Suppl. 2: 1-70.

Aviv, H., and P. Leder (1972) Purification of biologically active globin messenger RNA by chromatography on oligothymidylic acid-cellulose. Proc. Natl. Acad. Sci. USA 69: 1408-1412.

Barclay, N. (1979) Localization of the Thy-1 antigen in the cerebellar cortex of rat brain by immunofluorescence during postnatal development. J. Neurochem. 32: 1249-1257.

Bayon, A., W. J. Shoemaker, F. E. Bloom, A. Mauss, and R. Guillemin (1979) Perinatal development of the endorphin- and enkephalincontaining systems in the rat brain. Brain Res. 179: 93-101.

Bloom, F. E., E. L. F. Battenberg, R. J. Milner, and J. G. Sutcliffe (1985) Immunocytochemical mapping of 1B236, a brain specific neuronal polypeptide deduced from the sequence of a cloned mRNA. J. Neurosci. 5: 1781-1802.

Brown, P. C., T. D. Tlsty, and R. T. Schimke (1983) Enhancement of methotrexate resistance and dihydrofolate reductase gene amplification by treatment of mouse 3 T 6 cells with hydroxyurea. Mol. Cell. Biol. 3: 1097-1107.

Chaudhari, N., and W. E. Hahn (1983) Genetic expression in the developing brain. Science 220: 924-928.

DeGennaro, L. J., S. D. Kanazir, W. C. Wallace, R. M. Lewis, and P. Greengard (1983) Neuron-specific phosphoproteins as models for neuronal gene expression. Cold Spring Harbor Symp. Quant. Biol. 48: $337-345$.

Denhardt, D. T. (1966) A membrane-filter technique for the detection of complementary DNA. Biochem. Biophys. Res. Commun. 23:641646.

Ginzburg, I., T. Scherson, D. Giveon, L. Behar, and U. Z. Littauer (1982) Modulation of mRNA for microtubule-associated proteins during brain development. Proc. Natl. Acad. Sci. USA 79: 48924896.

Hawkes, R., E. Niday, and A. Matus (1982) MIT-23: A mitochondrial marker for terminal differentiation defined by a monoclonal antibody. Cell 28: 253-258.

Hinds, J. W. (1968) Autoradiographic study of histogenesis in the mouse olfactory bulb. I. Time of origin of neurons and neuroglia. $\mathbf{J}$. Comp. Neurol. 134: 287-304.

Kaplan, B. B., and C. E. Finch (1982) The sequence complexity of brain ribonucleic acids. In Molecular Approaches to Neurobiology, I. R. Brown, ed., pp. 71-98, Academic, New York.

Laemmli, U. K. (1970) Cleavage of structural proteins during the assembly of the head of bacteriophage T4. Nature 227: 680-683.

Lauder, J. M., and F. E. Bloom (1974) Ontogeny of monamine neurons in the locus coeruleus, raphe nuclei and substantia nigra of the rat. I. Cell differentiation. J. Comp. Neurol. 155: 469-482.

Lazarides, E., and J. Nelson (1983) Erythrocyte form of spectrin in cerebellum: appearance at a specific stage in the terminal differentiation of neurons. Science 222: 931-933.

Lewis, R. M., W. C. Wallace, S. D. Kanazir, and P. Greengard (1983) Expression of cell-type-specific neuronal phosphoproteins. Cold Spring Harbor Symp. Quant. Biol. 48: 347-354.

Malfroy, B., C. Bakhit, F. E. Bloom, J. G. Sutcliffe, and R. J. Milner 
530

Lenoir et al.

Vol. 6, No. 2, Feb. 1986

(1985) Brain-specific polypeptide 1B236 exists in multiple molecular forms. Proc. Natl. Acad. Sci. USA 82: 2009-2013.

Marangos, P. J., D. E. Schmechel, A. M. Parma, and F. K. Goodwin (1980) Developmental profile of neuron-specific (NSE) and nonneuronal (NNE) enolase. Brain Res. 190: 185-193.

Mile, I. L., and R. L. Sidman (1961) An autoradiographic analysis of histogenesis in the mouse cerebellum. Exp. Neurol. 4: 277-296.

Milner, R. J., and J. G. Sutcliffe (1983) Gene expression in rat brain. Nucleic Acids Res. 11: 5497-5520.

Palkovits, M. (1984) Distribution of neuropeptides in the central nervous system: a review of biochemical mapping studies. Prog. Nurobiol. 23: 151-189.

Rave, N., R. Crkvenjakov, and H. Boedtker (1979) Identification of procollagen mANAs transferred to diazobenzyloxymethyl paper from formaldehyde agarose gels. Nucleic Acid Res. 6: 3559-3567.

Rigby, P. W. J., M. Dieckman, C. Rhodes, and P. Berg (1977) Labeling deoxyribonucleic acid to high specific activity in vito by nick transration with DNA polymerase I. J. Mol. Biol. 113: 237-251.

Schibler, K., M. Tosei, A.-C. Pittet, L. Fabiani, and P. Wellames (1980) Tissue-specific expression of mouse $\alpha$-amylase genes. J. Mol. Biol. 142: 93-116.

Sutcliffe, J. G., R. J. Milner, T. M. Schinnick, and F. Bloom (1983a)
Identifying the protein products of brain specific genes with antibodies to chemically synthesized peptides. Cell $33: 671-682$.

Sutcliffe, J. G., R. J. Milner, and F. E. Bloom (1983b) Cellular localization and function of the proteins encoded by brain-specific mRNAs. Cold Spring Harbor Symp. Quant. Biol. 48: 477-484.

Sutcliffe, J. G., R. J. Miner, J. M. Gottesfeld, and W. Reynolds (1984) Control of neuronal gene expression. Science 225: 1308-1315.

Thomas, P. S. (1980) Hybridization of denatured RNA and small DNA fragments transferred to nitrocellulose. Proc. Natl. Acad. Sci. USA 77: 5201-5215.

Towbin, H., T. Staehlin, and J. Gordon (1979) Electrophoretic transfer of proteins from polyacrylamide gels to nitrocellulose sheets: Prosedore and some applications. Proc. Natl. Aced. Sci. USA 76: 43504354.

Turner, R. S., R. L. Raynor, G. J. Mazzei, P. R. Giard, and J. F. Kuo (1984) Developmental studies of phospholipid-sensitive $\mathrm{Ca}^{2+}$-dependent protein kinase and its substrates and of phosphoprotein posphatases in rat brain. Proc. Natl. Aced. Sci. USA 81: 3143-3147.

Wallace, J. A., and J. M. Lauder (1983) Development of the serotonergic system in the rat embryo: an immunocytochemical study. Brain Res. Bull. 10: 459-479. 